\title{
Determining the Effects of Psychosocial and Spiritual Support Among Patients With Substance Abuse: A Scoping Review
}

\author{
Nor Asiah Muhamad ${ }^{1, \dagger}$, Siti Nurhani Rafan ${ }^{2, \dagger}$, Nor Soleha Mohd Dali ${ }^{3}$, Norni Abdullah ${ }^{4}$, Norliza Chemi ${ }^{5}$, Hanisah \\ Shafie $^{6}$, Vikneswari Ayadurai ${ }^{7}$, Ruziaton Hasim ${ }^{8}$, Nor Anizah Muzaid ${ }^{9}$, Vengketeswara Rao ${ }^{10}$, Mohammed Faizal \\ Bakhtiar $^{3}$, Salmah Noordin ${ }^{11}$ \\ ${ }^{1}$ Sector for Evidence-based Healthcare, National Institutes of Health, Ministry of Health, Malaysia \\ ${ }^{2}$ Semenyih Health Clinic, Hulu Langat District Health Office, Selangor, Ministry of Health, Malaysia \\ ${ }^{3}$ Institute for Medical Research, National Institutes of Health, Ministry of Health, Malaysia \\ ${ }^{4}$ Department of Psychiatry, Klang Hospital, Selangor, Ministry of Health, Malaysia \\ ${ }^{5}$ Department of Psychiatry, Kajang Hospital, Selangor, Ministry of Health, Malaysia \\ ${ }^{6}$ Seri Kembangan Health Clinic, Petaling District Health Office, Selangor, Ministry of Health, Malaysia \\ ${ }^{7}$ Taman Medan Health Clinic, Petaling District Health Office, Selangor, Ministry of Health, Malaysia \\ ${ }^{8}$ Pandamaran Health Clinic, Klang District Health Office, Selangor, Ministry of Health, Malaysia \\ ${ }^{9}$ Kuala Selangor Health Clinic, Kuala Selangor District Health Office, Selangor, Ministry of Health, Malaysia \\ ${ }^{10}$ Ulu Yam Health Clinic, Hulu Selangor District Health Office, Selangor, Ministry of Health, Malaysia \\ ${ }^{11}$ Batu 9 Health Clinic, Hulu Langat District Health Office, Selangor, Ministry of Health, Malaysia \\ Correspondence: Nor Asiah Muhamad, Sector for Evidence-based Healthcare, National Institutes of Health, \\ Ministry of Health, Malaysia. E-mail: norasiahdr@gmail.com
}

$\dagger$ Share equal amount of work as first author

Received: February 26, 2020 Accepted: March 25, 2020 Online Published: May 11, 2020

doi:10.5539/gjhs.v12n7p48 URL: https://doi.org/10.5539/gjhs.v12n7p48

\begin{abstract}
Substance use disorder (SUD) has both social and public health problems with a substantial burden to society. SUD is a type of mental illness and has been described as a chronic relapsing disease. Treatments for SUD may include among others, psychosocial rehabilitation as a provision to comprehensive treatment to address the social and behavioral issues. These psychosocial components can address the issues of morality, spirituality, and religion. Religion and spirituality are believed to support SUD clients in the reduction of drug use, other associated high-risk behaviors, and criminal issues. In promoting treatment retention, it is important to reduce the drug use, maintain abstinence, and influence the self-esteem and coping ability of SUD clients. Hence, this review was conducted to determine the effects of psychosocial and spiritual support towards clients with substance abuse problem. We had followed the framework from Arksey and O'Malley's scoping review in identifying published studies from specific databases to be included in this review. A total of 8560 articles from various databases were screened. After removing duplicates, two authors independently screened 244 titles and abstracts. A total of eighteen articles were included in the final review. Out of eighteen studies, seventeen studies found that psychosocial support and spiritual needs have positive effect among substance abuse clients. Psychosocial and spiritual supports are beneficial among SUD clients due to various potential factors, such as religious reasons, personal beliefs or philosophical reasons, safety concerns, and a desire for improvements from substance abuse.
\end{abstract}

Keywords: Substance abuse, drug abuse, spiritual, psychosocial support, scoping review

\section{Introduction}

Drug addiction is a chronic relapsing illness that can be treated with pharmacological and non-pharmacological methods (Mohamed \& Marican, 2018). Treating substance abuse disorder (SUD) covers all aspects which leads to the action of abuse. This includes the behavioral and psychosocial components contributing to the condition (Mohamed \& Marican, 2018). Spiritual and social support among substance abuse clients may be important as a mechanic to cope with their addiction problem (Koenig, 2012). Strong religious and psychosocial support among 
clients were significant predictors for the prevention of relapse (Mohamed \& Marican, 2018). There were many spiritual and psychosocial intervention program in addition to the current program and treatment provided in rehabilitation therapy. Few of the studies worldwide had proven that the adjunct intervention program played an important role in the holistic management of addiction.

\subsection{Harm Reduction Program in Malaysia}

There are several studies in Malaysia involving the harm reduction program among substance abuse clients such as Medication Assisted Therapy (MAT), Needle Self-Exchange Program (NSEP) and condom (Mohamed \& Marican, 2018). With regards to the Medication Assisted therapy (MAT), the focus of the program was more on the retention rate and the associated factors affecting the retention rate (Mohamed \& Marican, 2018). Many of the SUD treatments viewed religion and spirituality as part of the comprehensive treatment and intervention. It has been reported that increase in religiosity and spirituality can protect them from high usage of substance (Koenig, 2012). It has been proven that high religiosity and spirituality support can promote less drug usage, also safer sex practice and reduction in criminals.

\subsection{Spiritual-Based Prevention Program in Community Setting}

A pilot program combining Methadone Maintenance Therapy (MMT) and religion with psychosocial counselling in mosque was successfully done in Malaysia. The program showed higher retention rate and less positive drugs usage after twelve months (Rashid et al., 2014). Spiritual therapy is one of the important components in the management of patients with SUD. This therapy also can improve their self-esteem and nurture a positive mental health (Khaledian et al., 2017). However, there was no local study that assessed the factors associated with relapse and spirituality in the treatment of substance abuse in Malaysia (M.H. et al., 2018). Furthermore, it has been shown that the rate of relapse was still high among those clients who were on treatment and have low spiritual practice score (M.H. et al., 2018). Apart from this, there was paucity of evidence on the effect of spiritual and psychosocial support among the clients who were receiving the SUD treatment. Therefore, this scoping review aims to identify the effect of psychosocial support and spiritual needs among substance abusers.

\section{Methods}

We conducted a scoping review with the aim to identify the research regarding the effects of psychosocial and spiritual treatment in the management of SUD clients.

We based our methodology on Arksey and O’Malley's five step framework for conducting a scoping review (Levac et al., 2010), including 1) identifying the research question; 2) identifying relevant studies; 3) study selection process; 4) charting the data; and 5) collating, summarizing and reporting the results. Each section is described in more detail below. A scoping review may offer succinct information and evidence regarding the psychosocial support and spiritual needs among methadone clients. Moreover, a review helps identify gaps in the psychosocial support among substance abuse clients. The scoping review methodology allowed us to summarize a wide range of evidence of effectiveness of psychosocial and spiritual treatment among substance abuse clients.

\subsection{Identifying the Research Question}

The present scoping review sought to answer:

i. The characteristics of psychosocial support and spiritual needs research among substance abuse.

ii. Clients worldwide in terms of the number of researches conducted, research design and methodology.

iii. The effects of psychosocial and spiritual support in the management of substance abuse.

iv. What are the future potential researches that can be done to identify the gaps in psychosocial support among substance abuse clients in Malaysia?

\subsection{Identifying Relevant Studies}

A comprehensive search using electronic databases such as PubMed, Scopus, Cochrane Library and Google Scholar was conducted. No limitations were placed on the date, and all databases were searched. We used subject headings, list of keywords and synonyms (support service, spiritual need, religious faith, opioid replacement therapy, methadone maintenance therapy, methadone client) as search terms by the research team members, in order to capture relevant studies (see Appendix 1). Boolean operators (OR, AND, NOT) including adjacencies and truncations were used to combine the keywords and related terms during the literature search. Two authors were independently screened the titles and abstracts for inclusion. Any discrepancies were resolved by a third author as a referee. After that, all the included studies were retrieved as full text. Two authors read the full text articles for inclusion in this review. Any disagreements were resolved through discussion and consensus. The authors also searched the reference lists of all included articles for any other relevant studies. 


\subsection{Study Selection Process}

We conducted this scoping review using the Preferred Reporting Items for Systematic Meta-Analysis framework (Moher, 2009). Figure 1 depicts the study selection process.

\subsection{Charting the Data}

Following full-text screening, the two reviewers charted each study chosen for inclusion using a standardized form, designed to gather common and comparable information on each study. The data extracted include year of publication, region, types of the psychosocial and spiritual support, and the effectiveness towards the substance abuse clients. The range of evidence identified any gaps in the literature.

\subsection{Collating, Summarizing and Reporting the Results}

The findings were tabled based on the number and types of studies according to the scopes of psychosocial and spiritual support among clients with substance abuse. Data were presented using table of findings based on the characteristics of the studies. The quality of studies was not assessed as it is outside the scope of the present scoping review. Several limitations of the studies were also gathered in order to address the research gap and to make useful recommendations for future research in addiction treatment program.

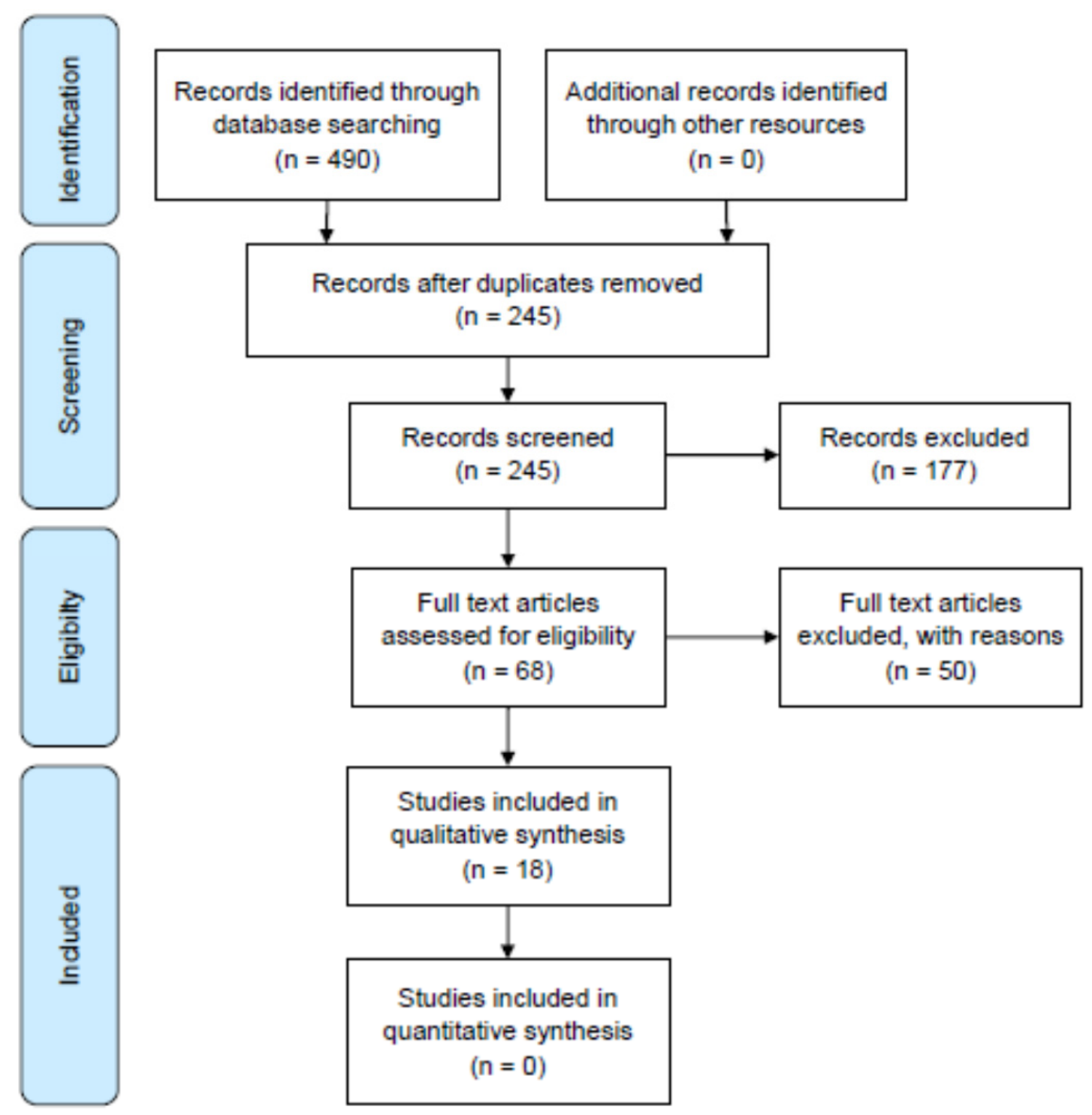

Figure 1. PRISMA flow diagram on selection process 


\section{Results}

Through a comprehensive search strategy, we identified eighteen eligible articles. We believe through our search strategy and the range of databases that was covered; we have captured all relevant literature that are specific to this scoping review. From the initial search through all databases, a total of 490 records were identified, with 245 records remaining after removing duplicates. Of 245 articles screened for titles and abstract, we excluded 177 articles. We assessed the full texts of the remaining 68 articles to determine their final eligibility and, included 18 articles in our analyses.

\subsection{Summary of Included Studies in the Review}

A total of eighteen articles were included in this review with the total sample size (n) of 6080 respondents. The summary of all studies is listed in Table 1, which consists of first author and year of publication, study title, place of study, study design, sample size (n), key finding, and notes on other relevant findings. Seven studies were conducted in the United States of America (Avants et al., 2001; Cucciare et al., 2016; Heinz et al., 2010; Pardini et al., 2000; Schoenthaler et al., 2015; Stahler et al., 2007; Sung \& Chu, 2013), six studies were conducted in Iran (Aghakhani et al., 2017; Jalali et al., 2019; Khaledian et al., 2017; Maarefvand et al., 2015; Navidian et al., 2016; Noormohammadi, 2017); two studies in Malaysia (M.H. et al., 2018; Rashid et al., 2014); and one study each was conducted in Vietnam (Khuong et al., 2018), South Africa (Stokes et al., 2018), and United Kingdom (Marsden et al., 2019), respectively. The most used study designs were cross-sectional study (Avants et al., 2001; Cucciare et al., 2016; Khuong et al., 2018; M.H. et al., 2018; Noormohammadi, 2017; Pardini et al., 2000), randomized controlled trial (Jalali et al., 2019; Khaledian et al., 2017; Maarefvand et al., 2015; Marsden et al., 2019), and qualitative study (Aghakhani et al., 2017; Rashid et al., 2014; Stokes et al., 2018). There was also retrospective study (Sung \& Chu, 2013), prospective study (Schoenthaler et al., 2015), case-control study (Stahler et al., 2007), qualitative and quantitative study (Heinz et al., 2010), and quasi-experimental study (Navidian et al., 2016). The findings revealed that psychosocial support increased the motivation and self-esteem of SUD clients. Strong religious belief and spiritual support decreased substance abuses and increased the positive outcome in the treatment of addiction. 
Table 1. Summary of 18 included studies

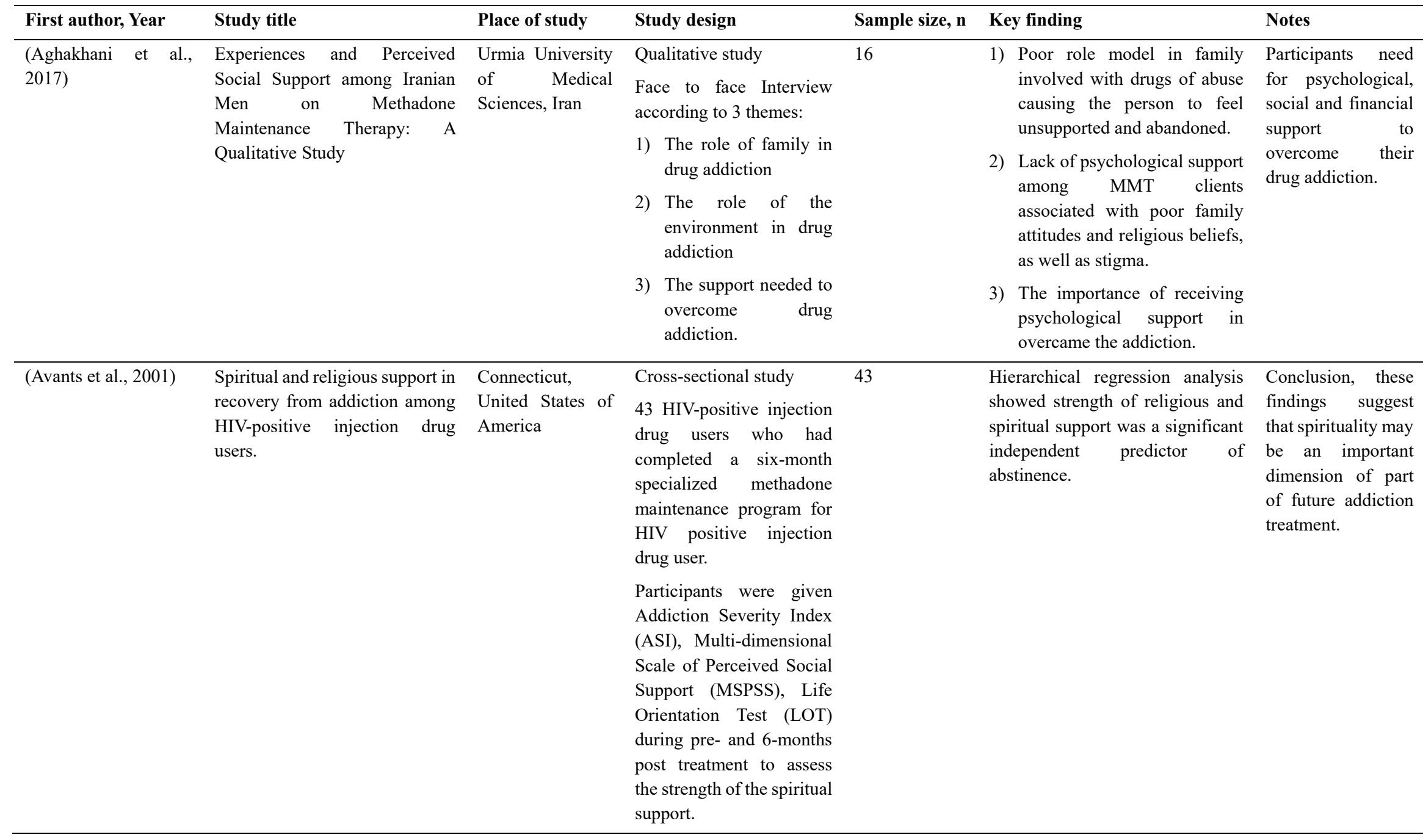




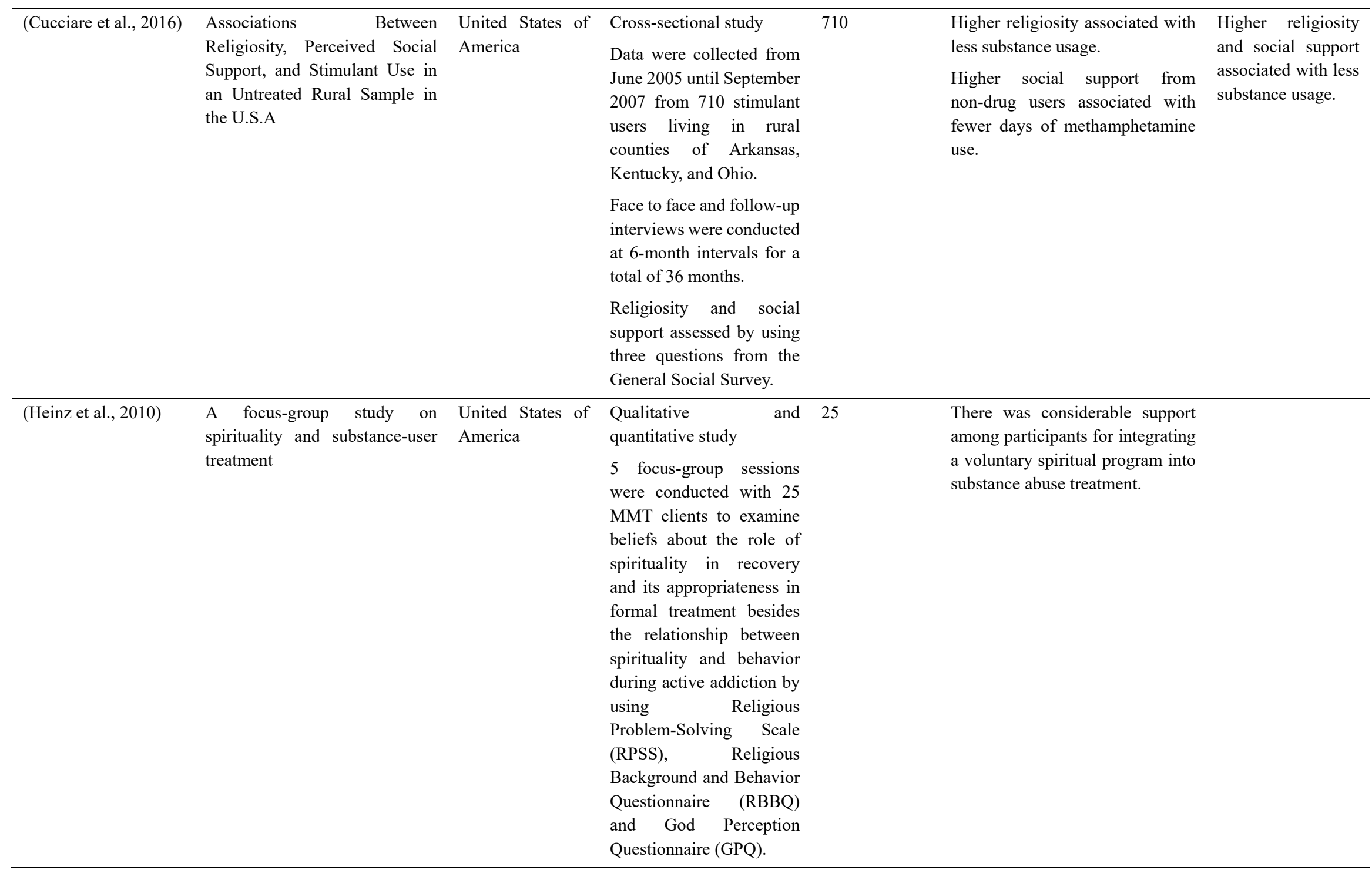




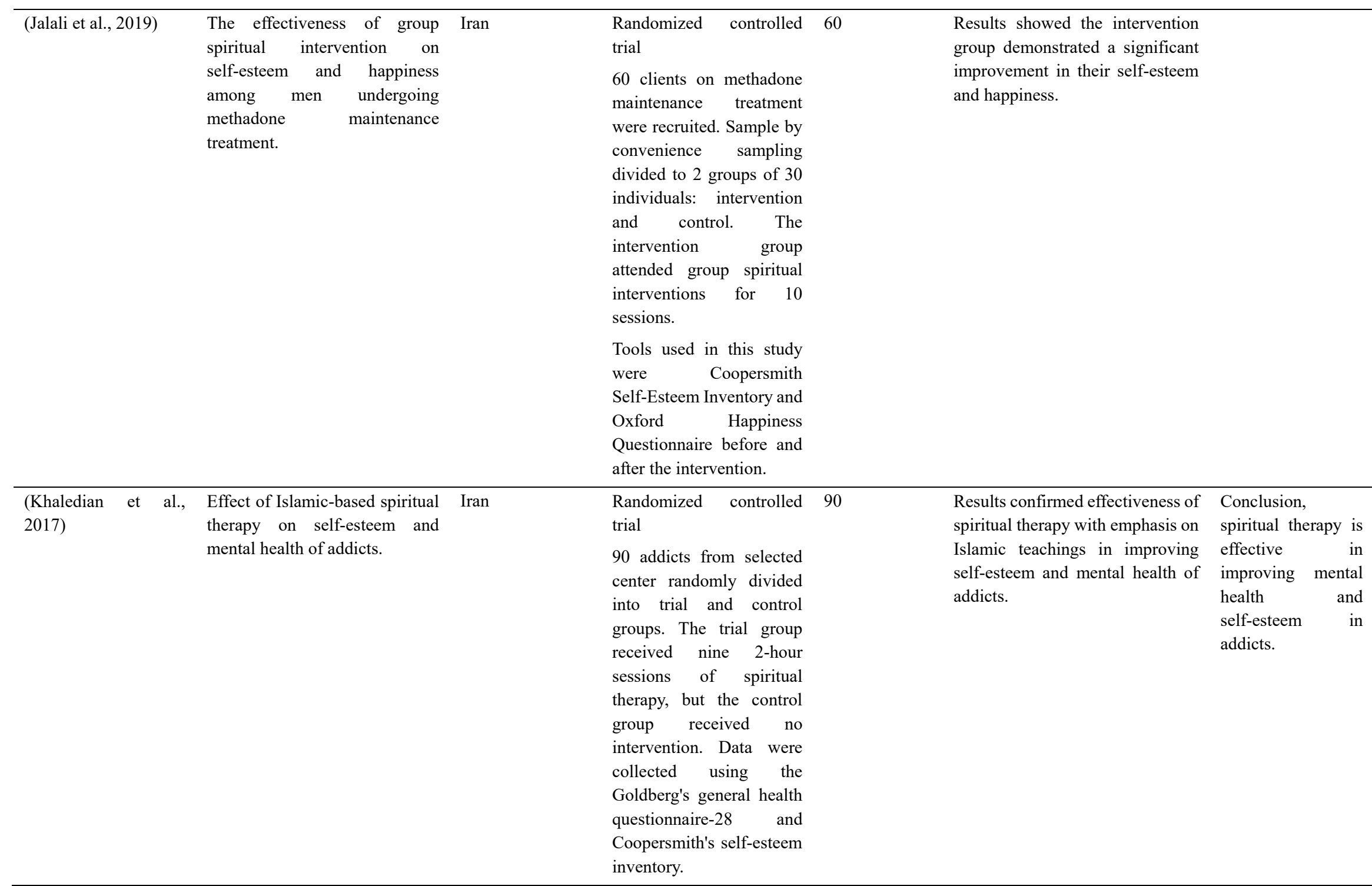




\begin{tabular}{|c|c|c|c|c|c|c|}
\hline (Khuong et al., 2018) & $\begin{array}{l}\text { Psychometric properties of the } \\
\text { medical outcomes study: social } \\
\text { support survey among } \\
\text { methadone maintenance patients } \\
\text { in Ho Chi Minh City, Vietnam: a } \\
\text { validation study. }\end{array}$ & $\begin{array}{l}\text { Ho Chi Minh } \\
\text { City, Vietnam }\end{array}$ & $\begin{array}{l}\text { Cross-sectional survey } \\
\text { This study to evaluate the } \\
\text { psychometric properties of } \\
\text { the Vietnamese version of } \\
\text { the Medical Outcomes } \\
\text { Study: Social Support } \\
\text { Survey (MOS-SSS) } \\
\text { among MMT patients. } \\
300 \text { patients were } \\
\text { conducted in a methadone } \\
\text { clinic with face-to-face } \\
\text { interview. }\end{array}$ & 300 & $\begin{array}{l}\text { The MOS-SSS is a reliable and } \\
\text { valid tool for measuring social } \\
\text { support in Vietnamese MMT } \\
\text { patients. } \\
\text { MOS-SSS had good internal } \\
\text { consistency with Cronbach's } \\
\text { alpha with overall scale of } 0.97 \text {. }\end{array}$ & $\begin{array}{l}\text { MOS-SSS is } \\
\text { reliable and } \\
\text { validated tools to } \\
\text { use. }\end{array}$ \\
\hline $\begin{array}{l}\text { (Maarefvand et al., } \\
\text { 2015) }\end{array}$ & $\begin{array}{l}\text { Community-based relapse } \\
\text { prevention for opiate } \\
\text { dependents: a randomized } \\
\text { community-controlled trial. }\end{array}$ & Tehran, Iran & $\begin{array}{l}\text { Randomized controlled } \\
\text { trial } \\
\text { Evaluate the effectiveness } \\
\text { of the community-based } \\
\text { relapse prevention } \\
\text { (CBRP) among opiate } \\
\text { dependent patients. } \\
71 \text { patients were enrolled } \\
\text { in this project. } 35 \text { patients } \\
\text { were assigned to receive } \\
\text { the intervention CBRP and } \\
36 \text { patients in control } \\
\text { group. }\end{array}$ & 71 & $\begin{array}{l}\text { Negative-drug-tests, } 45 \text { and } 90 \\
\text { days after discharge from } \\
\text { residential programs. } \\
\text { Abstinence rates were } \\
\text { significantly greater for patients } \\
\text { who received CBRP. }\end{array}$ & $\begin{array}{l}\text { CBRP was an } \\
\text { effective method } \\
\text { for RP among } \\
\text { opiate-dependents. }\end{array}$ \\
\hline $\begin{array}{l}\text { (Noormohammadi, } \\
2017 \text { ) }\end{array}$ & $\begin{array}{l}\text { Spiritual well-being and } \\
\text { associated factors with relapse } \\
\text { in opioid addicts. }\end{array}$ & Shahrekord, Iran & $\begin{array}{l}\text { Cross-sectional study } \\
\text { To determine spiritual } \\
\text { well-being and factors } \\
\text { associated with relapse } \\
\text { among opioid addicts. } \\
312 \text { eligible addicted } \\
\text { patients were enrolled in } \\
\text { the study. } \\
\text { The tool used is Paloutzian } \\
\text { and Ellison's Spiritual }\end{array}$ & 312 & $\begin{array}{l}\text { Believing in God's presence and } \\
\text { believing in a higher power that is } \\
\text { component of spiritual health are } \\
\text { predictors of positive outcomes in } \\
\text { treatment of addiction. }\end{array}$ & \\
\hline
\end{tabular}




\begin{tabular}{|c|c|c|c|c|c|c|}
\hline & & & Well-being Scale. & & & \\
\hline (Rashid et al., 2014) & $\begin{array}{l}\text { A mosque-based methadone } \\
\text { maintenance treatment strategy: } \\
\text { Implementation and pilot } \\
\text { results. }\end{array}$ & Malaysia & $\begin{array}{l}\text { Qualitative study } \\
36 \text { Malay Muslim heroin } \\
\text { users. } \\
\text { Urine drug test, } \\
\text { self-reported measures in } \\
\text { various dimensions and } \\
\text { quality of life collected at } \\
\text { baseline and } 12 \text { months. }\end{array}$ & 36 & $\begin{array}{l}\text { 12- months retention rate was } \\
80 \% \text {. } \\
35 \text { participants after } 12 \text { months } \\
\text { tested negative for opioid and } \\
\text { other substances. }\end{array}$ & $\begin{array}{l}\text { Self-report } \\
\text { measures showed } \\
\text { significant } \\
\text { reductions in } \\
\text { degree of variety of } \\
\text { drug use, } \\
\text { improvement in } \\
\text { general health, } \\
\text { psychological and } \\
\text { social functioning. }\end{array}$ \\
\hline (Stahler et al., 2007) & $\begin{array}{l}\text { A faith-based intervention for } \\
\text { cocaine-dependent Black } \\
\text { women. }\end{array}$ & $\begin{array}{l}\text { United States of } \\
\text { America }\end{array}$ & $\begin{array}{l}\text { Case-control study } \\
18 \text { women recruited over } \\
\text { 1-year period from } \\
\text { residential drug treatment } \\
\text { program. } \\
\text { Tool measures on } \\
\text { Effectiveness of Standard } \\
\text { Treatment plus Bridges or } \\
\text { Standard Treatment with } \\
\text { an Attention Control. } \\
\text { Outcome measures on } \\
\text { treatment retention, } \\
\text { attendance and abstinence } \\
\text { from drugs at 3- and } \\
6 \text {-months post intake. }\end{array}$ & 18 & $\begin{array}{l}\text { Bridges program } \begin{array}{r}\text { promote } \\
\text { treatment retention, attendance }\end{array} \\
\text { and drug abstinence. }\end{array}$ & \\
\hline (Stokes et al., 2018) & $\begin{array}{l}\text { Narrating the journey of } \\
\text { sustained recovery from } \\
\text { substance use disorder. }\end{array}$ & South Africa & $\begin{array}{l}\text { Qualitative study } \\
\text { Face to face interview } \\
\text { among } 15 \text { participants by } \\
\text { using theoretical } \\
\text { framework Schlossberg's } \\
\text { Transition Process Model } \\
\text { was used as for this study. }\end{array}$ & 15 & $\begin{array}{l}\text { In Schlossberg's Transitional } \\
\text { Process Model and spirituality has } \\
\text { been found to influence coping } \\
\text { ability, self-esteem, realization of } \\
\text { personal strengths and resilience. }\end{array}$ & \\
\hline
\end{tabular}




\begin{tabular}{|c|c|c|c|c|c|c|}
\hline (Sung \& Chu, 2013) & $\begin{array}{l}\text { The varieties of religious } \\
\text { experience and the retention of } \\
\text { clients in Taiwanese faith-based } \\
\text { residential drug user treatment. }\end{array}$ & $\begin{array}{l}\text { United States of } \\
\text { America }\end{array}$ & $\begin{array}{l}\text { Retrospective study } \\
\text { A total of } 707 \text { clients files } \\
\text { who admitted to faith } \\
\text { based residential treatment } \\
\text { were analyzed from year } \\
2000 \text { to } 2009 \text { to look at the } \\
\text { type of religious faith } \\
\text { associated with the } \\
\text { treatment retention and } \\
\text { completion. }\end{array}$ & 707 & $\begin{array}{l}\text { Socio-religious identities are the } \\
\text { main precursor of positive } \\
\text { outcome in the treatment. }\end{array}$ & $\begin{array}{l}\text { Religious identities } \\
\text { significantly } \\
\text { associated with } \\
\text { good treatment } \\
\text { outcome. }\end{array}$ \\
\hline (Pardini et al., 2000) & $\begin{array}{l}\text { Religious faith and spirituality } \\
\text { in substance abuse recovery } \\
\text { determining the mental health } \\
\text { benefits. }\end{array}$ & $\begin{array}{l}\text { Santa Clara } \\
\text { county, } \\
\text { California, United } \\
\text { States of America }\end{array}$ & \begin{tabular}{lrr}
\multicolumn{3}{l}{ Cross-sectional study } \\
$236 \quad$ participants \\
recovering & & from \\
alcoholism or & drug \\
addiction by & using \\
self-administered & Santa \\
Clara Strength & of \\
Religious & Faith \\
Questionnaire. &
\end{tabular} & 236 & $\begin{array}{l}\text { Individuals recovering from } \\
\text { substance abuse tend to place } \\
\text { great importance on prayer, belief } \\
\text { in a God, and a strong sense of } \\
\text { faith. } \\
\text { Religious faith and spirituality are } \\
\text { related to positive mental health } \\
\text { outcomes. }\end{array}$ & \\
\hline (Marsden et al., 2019) & $\begin{array}{l}\text { Efficacy and cost-effectiveness } \\
\text { of an adjunctive personalized } \\
\text { psychosocial intervention in } \\
\text { treatment-resistant maintenance } \\
\text { opioid agonist therapy: a } \\
\text { pragmatic, open-label, } \\
\text { randomized controlled trial. }\end{array}$ & $\begin{array}{l}\text { Specialist UK } \\
\text { National Health } \\
\text { Service } \\
\text { community } \\
\text { addictions clinic } \\
\text { in London, United } \\
\text { Kingdom }\end{array}$ & $\begin{array}{l}\text { Randomized controlled } \\
\text { trial } \\
\text { Study between } 7 \text { June } \\
2013 \text { until } 21 \text { December } \\
\text { 2015. Database locked at } \\
19 \text { April } 2017 \\
136 \text { in psychosocial } \\
\text { intervention group } \\
137 \text { control group } \\
\text { Treatment by personalized } \\
\text { psychosocial intervention } \\
\text { (flexible toolkit of } \\
\text { psychological-change } \\
\text { methods, contingency } \\
\text { management to reinforce } \\
\text { abstinence, recovery } \\
\text { activities, and clinic }\end{array}$ & 273 & $\begin{array}{l}22 \text { (intervention) vs } 9 \text { (control) } \\
\text { More cost effective in intervention } \\
\text { group } \\
\text { QALY higher in intervention } \\
\text { group }\end{array}$ & $\begin{array}{l}\text { In maintenance } \\
\text { opioid agonist } \\
\text { therapy, an } \\
\text { adjunctive } \\
\text { personalized } \\
\text { psychosocial } \\
\text { intervention in } \\
\text { addition to standard } \\
\text { therapy was } \\
\text { efficacious and } \\
\text { cost-effective } \\
\text { compared with } \\
\text { standard therapy } \\
\text { alone at helping } \\
\text { treatment-resistant } \\
\text { patients abstain } \\
\text { from using illicit } \\
\text { and non-prescribed }\end{array}$ \\
\hline
\end{tabular}




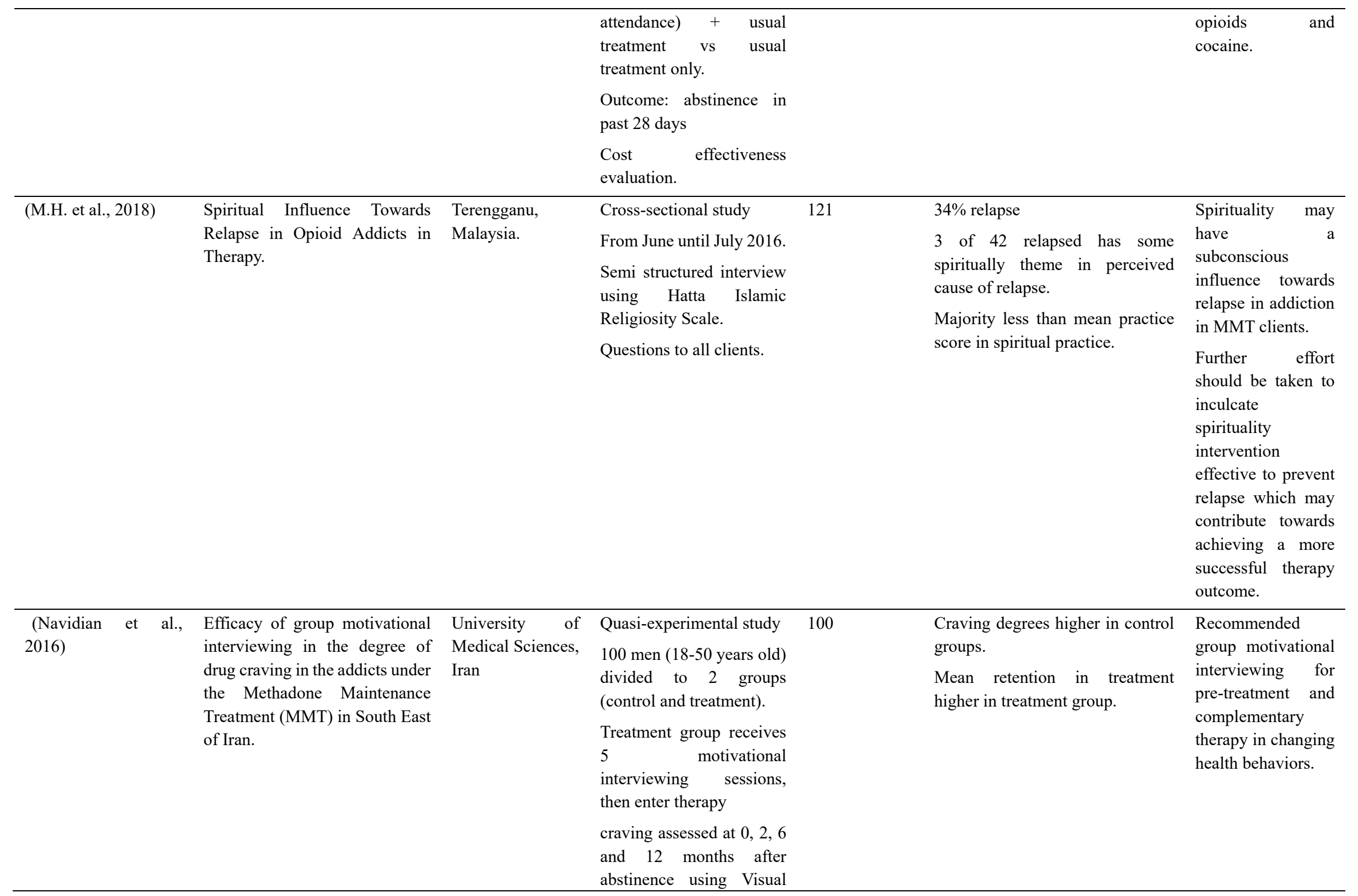




\begin{tabular}{|c|c|c|c|c|c|}
\hline & & & $\begin{array}{l}\text { Cue-induced Craving Task } \\
\text { analysis by descriptive } \\
\text { statistics, independent } \mathrm{T} \\
\text { test, analysis of variance. }\end{array}$ & & \\
\hline $\begin{array}{l}\text { (Schoenthaler et al., } \\
\text { 2015) }\end{array}$ & $\begin{array}{l}\text { NIDA-Drug } \\
\text { Treatment Outcome Study } \\
\text { (DATOS) } \\
\text { Relapse as a Function of } \\
\text { Spirituality/Religiosity }\end{array}$ & $\begin{array}{l}\text { United States of } \\
\text { America }\end{array}$ & $\begin{array}{l}\text { Prospective study } \\
\text { Recruitment of clients } \\
\text { taken from } 11 \\
\text { representative cities. } \\
\text { Clients were involved in } \\
\text { the drug abuse treatment } \\
\text { during } 1991 \text { and } 1993 . \\
\text { Four types of programs: } \\
\text { 1) Outpatient methadone } \\
\text { 2) Short-term inpatient } \\
\text { 3) Long-term residential } \\
\text { 4) Outpatient residential } \\
\text { Data obtained were } \\
\text { twelve-moth relapse and } \\
\text { spirituality. }\end{array}$ & 2947 & $\begin{array}{l}\text { Clients with higher spiritual belief } \\
\text { have less use of alcohol, cocaine, } \\
\text { heroin and marijuana. } \\
\text { Crack users who did not believe in } \\
\text { the importance of religion were } \\
\text { reported to use less crack than the } \\
\text { spiritual clients. } \\
\text { Stronger religious belief is } \\
\text { associated with remission from } \\
\text { substance abuse except crack. }\end{array}$ \\
\hline
\end{tabular}




\section{Discussion}

Many religions in the world oppose the intoxicating substances as they can do more harm to a person (M.H. et al., 2018). The importance of treatments for SUD clients consist of pharmacological treatment(s) and psychosocial support that includes elements of spiritual care to achieve the optimal effect of the management. Poor psychological support among family members and lack of religious beliefs among MMT clients cause them to feel demotivated, abandoned and, have low self-esteem. This psyche will increase the problem of addiction and relapse (Aghakhani et al., 2017). Behavioral practices such as motivational- and psychoeducation-based approaches, counseling, and family and peer's involvement in the care process contributes to the comprehensiveness of SUD treatment (Timko et al., 2015). SUD clients need psychosocial and spiritual support in order to achieve remission or complete their treatment. They usually feel neglected by the people around them, and the stigma about their situation makes them return to the substance abuse.

In a study by Avants et al. (2001), a few questionnaires were given to the SUD clients, especially the HIV-positive clients, to assess the strength of spiritual support among them. The results showed that the strength of religious and spiritual support was a significant independent predictor of abstinence. In addition, higher religiosity among MMT clients and good social support from non-drug users were associated with less substance usage (Cucciare et al., 2016). In a randomized controlled intervention study, it was revealed that spiritual intervention showed success in improving the clients' self-esteem and happiness (Jalali et al., 2019). Apart from that, Community Based Relapse Prevention (CBRP) program also played an important role in managing relapse among SUD clients (Maarefvand et al., 2015). Based on the study, clients who had received CBRP have abstained from drug use between 6 weeks and 3 months after completing the program. Moreover, it was shown that individuals recovering from substance abuse had huge belief in God with a strong sense of faith, and they developed positive mental health outcomes from that belief (Pardini et al., 2000). In Malaysia, a pilot study of mosque-based MMT intervention program had shown significant reductions in the degree and of variety of the drugs used, and also improvement of not just the clients' general health, but also psychological and social functioning (Rashid et al., 2014). The study found that the effect on retention rate among clients' participation in 12 months was high, at $80 \%$. There was only one client who tested positive for opioid substance among 36 clients who joined the program (Rashid et al., 2014). Besides that, a cross-sectional study conducted on 121 SUD clients revealed that only $34 \%$ have relapsed when the treatment was associated with spiritual support (M.H. et al., 2018).

Our scoping review have a few limitations. Firstly, we have included only 18 studies involving 6,080 respondents. This is comparatively small. Secondly, only English articles were included, which may cause publication bias. Finally, the role of spiritual and psychosocial therapists was not discussed in detail. More information is needed to further elucidate the role of the therapists and how they deliver the content of the therapy.

\section{Conclusion}

Substance abuse continues to be a major clinical and social problem the world over. Besides drug treatments, psychosocial therapy and the clients religious/spiritual beliefs and practices play significant roles in achieving remission and/or completing their treatment. Therefore, this scoping review can act as a guiding document in determining the need of adding psychosocial and spiritual support in the substance abuse clients' management.

\section{Acknowledgements}

We thank the Director General of Health, Ministry of Health, Malaysia for permission to publish this report.

\section{Competing Interests Statement}

The authors declare that there are no competing or potential conflicts of interest.

\section{References}

Aghakhani, N., Lopez, V., \& Cleary, M. (2017). Experiences and Perceived Social Support among Iranian Men on Methadone Maintenance Therapy: A Qualitative Study. Issues in Mental Health Nursing, 38(9), 692-697. https://doi.org/10.1080/01612840.2017.1341586

Avants, S. K., Warburton, L. A., \& Margolin, A. (2001). Spiritual and Religious Support in Recovery from Addiction Among HIV-Positive Injection Drug Users. Journal of Psychoactive Drugs, 33(1), 39-45. https://doi.org/10.1080/02791072.2001.10400467

Cucciare, M. A., Han, X., Curran, G. M., \& Booth, B. M. (2016). Associations Between Religiosity, Perceived Social Support, and Stimulant Use in an Untreated Rural Sample in the U.S.A. Substance Use \& Misuse, 51(7), 823-834. https://doi.org/10.3109/10826084.2016.1155611 
Heinz, A. J., Disney, E. R., Epstein, D. H., Glezen, L. A., Clark, P. I., \& Preston, K. L. (2010). A Focus-Group Study on Spirituality and Substance-User Treatment. Substance Use \& Misuse, 45(1-2), 134-153. https://doi.org/10.3109/10826080903035130

Jalali, A., Behrouzi, M. K., Salari, N., Bazrafshan, M.-R., \& Rahmati, M. (2019). The Effectiveness of Group Spiritual Intervention on Self-esteem and Happiness Among Men Undergoing Methadone Maintenance $\begin{array}{lllll}\text { Treatment. Current Drug Research } & \text { Reviews, }\end{array}$ https://doi.org/10.2174/1874473711666180510164420

Khaledian, M., Pishvaei, M., Karami Baghteyfouni, Z., \& Smaeili, M. (2017). Effect of Islamic-based spiritual therapy on self-esteem and mental health of addicts. JRH, 7(2), 719-728. Retrieved from http://jrh.gmu.ac.ir/browse.php?a_id=1129\&sid=1\&slc_lang=en

Khuong, L. Q., Vu, T.-V. T., Huynh, V.-A. N., \& Thai, T. T. (2018). Psychometric properties of the medical outcomes study: Social support survey among methadone maintenance patients in Ho Chi Minh City, Vietnam: a validation study. Substance Abuse Treatment, Prevention, and Policy, 13(1), 8. https://doi.org/10.1186/s13011-018-0147-4

Koenig, H. G. (2012). Religion, Spirituality, and Health: The Research and Clinical Implications. ISRN Psychiatry 2012, 1-33. https://doi.org/10.5402/2012/278730

Maarefvand, M., Eghlima, M., Rafiey, H., Rahgozar, M., Tadayyon, N., Deilamizadeh, A., \& Ekhtiari, H. (2015). Community-Based Relapse Prevention for Opiate Dependents: A Randomized Community Controlled Trial. Community Mental Health Journal, 51(1), 21-29. https://doi.org/10.1007/s10597-014-9772-1

Marsden, J., Stillwell, G., James, K., Shearer, J., Byford, S., Hellier, J., Kelleher, M., Kelly, J., Murphy, C., \& Mitcheson, L. (2019). Efficacy and cost-effectiveness of an adjunctive personalised psychosocial intervention in treatment-resistant maintenance opioid agonist therapy: A pragmatic, open-label, randomised controlled trial. The Lancet Psychiatry, 6(5), 391-402. https://doi.org/10.1016/S2215-0366(19)30097-5

Mohamed, M. N., \& Marican, S. (2018). Treatment and Rehabilitation of Substance Use Disorder: Significance of Islamic Input in Malaysia. Int. J. Hum. Health Sci., 2, 209. http://dx.doi.org/10.31344/ijhhs.v2i4.57

M.H., N., M., N. H., C.M., K., D., N., \& A.A., A. (2018). Spiritual Influence Towards Relapse in Opioid Addicts in Therapy. International Medical Journal Malaysia, 17, 71-74. Retrieved from https://web.a.ebscohost.com/abstract?direct=true\&profile=ehost\&scope $=$ site\&authtype $=$ crawler\&jrnl=1823 4631\&AN=131626673\&h=CAyMczxeXQSoESfzHIhhUxatjavO1U0jSgqLgojru4lFvSOhE6Bd1zB9\%2bwa ie0EbmHH6mrV\%2bCpyV1S09\%2b3InRg\%3d\%3d\&crl=c\&resultNs=AdminWebAuth\&resultLocal=ErrC rlNotAuth\&crlhashurl=login.aspx\%3fdirect $\% 3 \mathrm{dtrue} \% 26$ profile $\% 3 \mathrm{dehost} \% 26$ scope $\% 3 \mathrm{dsite} \% 26$ authtype $\% 3$ dcrawler\%26jrnl\%3d18234631\%26AN\%3d131626673

Navidian, A., Kermansaravi, F., Tabas, E. E., \& Saeedinezhad, F. (2016). Efficacy of Group Motivational Interviewing in the Degree of Drug Craving in the Addicts Under the Methadone Maintenance Treatment (MMT) in South East of Iran. Archives of Psychiatric Nursing, 30(2), 144-149. https://doi.org/10.1016/j.apnu.2015.08.002

Noormohammadi, M.-R. (2017). Spiritual Well-Being and Associated Factors with Relapse in Opioid Addicts. JOURNAL OF CLINICAL AND DIAGNOSTIC RESEARCH. https://doi.org/10.7860/JCDR/2017/22819.9587

Pardini, D. A., Plante, T. G., Sherman, A., \& Stump, J. E. (2000). Religious faith and spirituality in substance abuse recovery. Journal of Substance Abuse Treatment, 19(4), 347-354. https://doi.org/10.1016/S0740-5472(00)00125-2

Rashid, R. A., Kamali, K., Habil, M. H., Shaharom, M. H., Seghatoleslam, T., \& Looyeh, M. Y. (2014). A mosque-based methadone maintenance treatment strategy: Implementation and pilot results. International Journal of Drug Policy, 25(6), 1071-1075. https://doi.org/10.1016/j.drugpo.2014.07.003

Schoenthaler, S. J., Blum, K., Braverman, E. R., Giordano, J., Thompson, B., Oscar-Berman, M., ... \& Gold, M. S. (2015). NIDA-Drug Addiction Treatment Outcome Study (DATOS) Relapse as a Function of Spirituality/Religiosity. Journal of Reward Deficiency Syndrome, 01(01). https://doi.org/10.17756/jrds.2015-007

Stahler, G. J., Kirby, K. C., \& Kerwin, M. E. (2007). A Faith-Based Intervention for Cocaine-Dependent Black Women. Journal of Psychoactive Drugs, 39(2), 183-190. https://doi.org/10.1080/02791072.2007.10399877 
Stokes, M., Schultz, P., \& Alpaslan, A. (2018). Narrating the journey of sustained recovery from substance use disorder. Substance Abuse Treatment, Prevention, and Policy, 13(1), 35. https://doi.org/10.1186/s13011-018-0167-0

Sung, H.-E., \& Chu, D. C. (2013). The Varieties of Religious Experience and the Retention of Clients in Taiwanese Faith-Based Residential Drug User Treatment. Substance Use \& Misuse, 48(12), 1219-1232. https://doi.org/10.3109/10826084.2013.805597

\section{Appendixes}

\section{Appendix 1 (Pubmed search)}

1. Search 'support service'[Title/Abstract]

2. Search 'spiritual need'[Title/Abstract]

3. Search 'religious faith'

4. Search (\#1 OR \#2 OR \#3) $=5905$

5. Search 'opioid replacement therapy'[Title/Abstract]

6. Search 'methadone maintenance therapy'[Title/Abstract]

7. Search 'methadone client'[Title/Abstract]

8. Search 'opioid dependence'

9. Search $(\# 5$ OR \#6 OR \#7 OR \#8) $=3044$

10. Search (\#4 AND \#8)

Total 9

\section{Appendix 2 (Cochrane search)}

1. Search 'support service'

2. Search 'spiritual need'

3. Search 'religious faith'

4. Search (\#1 OR \#2 OR \#3) = 10716

5. Search 'opioid replacement therapy'

6. Search 'methadone maintenance therapy'

7. Search 'methadone client'

8. Search 'opioid dependence'

9. Search (\#5 OR \#6 OR \#7 OR \#8) = 3918

10. Search (\#4 AND \#9)

Total 81

\section{Appendix 3 (Google scholar)}

1. Search: support service OR spiritual need OR religious faith AND opioid replacement therapy OR methadone maintenance therapy OR methadone client

2. Since 2015

3. Include citations

Total: 8330 


\section{Appendix 4 (Scopus)}

1. Search "support services" OR "spiritual need" OR "religious faith" AND "opioid replacement therapy" OR "methadone maintenance therapy" OR "methadone client" OR "opioid dependence".

Total: 141

\section{Copyrights}

Copyright for this article is retained by the author(s), with first publication rights granted to the journal.

This is an open-access article distributed under the terms and conditions of the Creative Commons Attribution license (http://creativecommons.org/licenses/by/4.0/). 